\title{
Co-ordination between R\&D and Human Resource in the post catching-up era
}

\author{
Gyu-hee Hwang \\ Research fellow at KRIVET, Seoul, 135-949, Republic of Korea
}

\begin{abstract}
Korea has entered into the Post Catching-up era and the necessity of new innovation strategy in response is being raised. This study argues the necessity of new innovation strategy and discusses the issue of co-ordination between R\&D and Human Resource for that as the key factor. From empirical analysis, there seems to be restricted inflow of outstanding human resources to manufacturing sectors and lowering effectiveness of major even with the improved compatibility between major and job. Especially, it is severe in the industries with high $R \& D$ investment. It can be interpreted as an incoordination of the technological innovation efforts from the aspect of $R \& D$ investment with human resource utilization from the aspect of new human resource. The analytical result and interpretation suggests that there should be more active improvement on the co-ordination between innovative manufacturers' efforts and human resource utilization, in order to keep sustainable development.
\end{abstract}

Key words: Co-ordination, $R \& D$, usefulness of major for work, analysis of Input/Output, wage analysis for the engineering graduate.

\section{RAISING ISSUES}

Korea has gone through a successful catching-up process and reached the stage to build new innovation system after year 2000. But this kind of awareness and raising issue has been remained at normative and declaratory level, and direction and policy based on theoretical foundation and proof analysis have not proceeded([1]-[2]). To this matter, this study tries to verify the stagnation of R\&D input result and the necessity of new innovation policy, and to demonstrate the immediate need of new innovation policy from the perspective of co-ordination between R\&D and human resource.

The issues and assertion raised by this study focus on emphasizing the co-ordination with R\&D investment more as the core element of innovation system in the aspect of process surrounding national scale knowledge forming \& utilizing, which is the another aspect of national innovation system. That has a priority over restructuring the system through element improvement of innovation system such as an increase of R\&D investment, in order to achieve transition to post catching-up type innovation system from catching-up innovation system, which is based on the mechanism of imitative learning. In order to verify that, this study tries to carry out changes on $R \& D$ output requirements effect by industry based on 'Input-Output table' \& attached 'Employment table', usefulness effect between major and job in wage function (especially focusing on engineering school) of university graduates using 'Graduates Occupational Mobility Survey (GOMS)', and

\footnotetext{
* Corresponding author, Email: g.hwang@krivet.re.kr Manuscript received Jul. 12, 2012; revised Sep 7, 2012; accepted Sep 17, 2012
}

exploratory analysis on knowledge influx and utilization per industry by linking above changes and effects.

In theoretical aspect, this study is an extension of research stream for National Innovation System. The studies on National Innovation System include firstly formation and the natural development of National Innovation System's composing elements such as government-university-enterprise-financial institute with focus on institutional structure, exemplified in Freeman[3] from Great Britain with explanation on Japanese production system by focusing on evolutionary aspect and Nelson[4] with explanation on American technological development. Secondly, there is another type of technological innovation theory of Lundvall[5] and Edquist[6] in Europe who paid less attention on the composing elements of national innovation system by emphasizing learning process aspect through user-producer interactions. While the general study current is divided into institutional structure and learning process, study current that emphasizes systematic structure had been deployed into regional innovation system or industry innovation system according to analysis level. The stream of innovation policy in Korea also had emphasized this systematic structure. In the aspect in which the analysis on the development of corporate innovation ability proceeds mainly with innovation achievements such as R\&D, and additionally focusing on the institutional-structural connection with national policy and overseas export, it can be classified as institutional structure. This kind of classification standard is same in Kim[7], but Kim[8] developed the discussion mainly on learning process.

In contrast with regional innovation system which has discussed innovation policy focused on the role of university- 
enterprise-government, this study will focus on learning process. This is to emphasize the qualitative side of Human Resource rather than quantitative side. In this context, learning process is an aspect of Human Resource, and when innovation efforts from each industry coordinate successfully with this learning process, the expected innovation achievements can be realized. Especially, while the method of creating knowledge has changed from Mode 1 to Mode 2 in the middle of spreading convergence technology([9]-[11]), the imitation based skill forming strategy in Catching-up period reached its limit and therefore, building new human resource policy is necessary in the post catching-up era. Viotti[12] conceptualized the innovation-learning systems of latecomer catching-up countries as National Learning System (NLS). This study tries to prove the necessity of building new National Learning System (NLS) in the context of Co-ordination among R\&D human resources in Post Catching-up stage.

This study will present that the ripple effect of $R \& D$ on output and employment has been stagnated even with the increase of R\&D input when looking into the Input-Output table of 2005, 2007 and 2009 in the chapter 2. In the chapter 3, the wage effect of usefulness between major and job of newly graduates of engineering school is analyzed at the level of 28 industry classification by using GOMS data, in which usefulness effect between major and job had declined while passing 2008-2010. In the aspect of wage as the proxy variable of output and productivity, this receding usefulness between major and job could be a cause to R\&D effect stagnation in the previous chapter. The analysis done in the chapter 2 and 3 are combined in the chapter 4 , while presenting the possibility of realizing expected innovation achievement when the learning process focusing on Human Resource aspect successfully coordinate with innovation efforts. The achievement, limitation and following subject are discussed in the chapter 5 .

\section{R\&D RIPPLE EFFECT IN POST CATCHING-UP ERA}

The key of technological innovation in the post catching-up stage has to be something that goes beyond imitation [8], and the importance of R\&D for that matter is emphasized more and more. This ripple effect of $R \& D$ to the entire industry can be displayed through Input-Output table. The basic structure of Input-Output matrix is as below.

\section{$A X+Y-M=X$ \\ A: input coefficient, \\ $X$ : industry output, \\ $Y$ : final demand, \\ M: exports}

When resolve this for $\mathrm{X}, X=(I-A)^{-1}(Y-M)$ is the result, and $(I-A)^{-1}$ is called Leontief inverse matrix or total requirements matrix.
Table 1. Total requirements table

\begin{tabular}{|l|c|c|c|c|}
\hline & Industry $\mathbf{1}$ & Industry $\mathbf{2}$ & Industry $\mathbf{3}$ & Industry $\mathbf{4}$ \\
\hline Industry $\mathbf{1}$ & $r_{11}$ & $r_{12}$ & $\ldots$ & $S_{1}$ \\
\hline Industry 2 & $r_{21}$ & $:$ & $\ldots$ & \\
\hline Industry $\mathbf{3}$ & $:$ & $:$ & & \\
\hline Column total & $R_{1}$ & $\ldots$ & & \\
\hline
\end{tabular}

Table 2. R\&D Input coefficient by Industry (\%)

\begin{tabular}{|l|c|c|c|}
\hline \multicolumn{1}{|c|}{ Product } & $\mathbf{2 0 0 5}$ & $\mathbf{2 0 0 7}$ & $\mathbf{2 0 0 9}$ \\
\hline Agriculture, forestry and fisheries & .024 & .031 & .028 \\
\hline Mining and quarrying & .049 & .049 & .055 \\
\hline Food and beverages & .133 & .174 & .174 \\
\hline Textiles, textile and leather & .097 & .125 & .130 \\
\hline Wood, cork, pulp and paper & .142 & .231 & .244 \\
\hline Printing and publishing & .337 & .472 & .458 \\
\hline Coal and refined petroleum & .115 & .224 & .167 \\
\hline Chemicals and chemical & .145 & .361 & .511 \\
\hline Other non-metallic mineral & .529 & .644 & .708 \\
\hline Basic metals & .627 & .895 & .022 \\
\hline Fabricated metal & .366 & .488 & .526 \\
\hline Machinery & .567 & .907 & .124 \\
\hline Electrical equipment & .919 & .627 & .747 \\
\hline Optical equipment & .232 & .815 & .073 \\
\hline Transport equipment & .856 & .029 & .085 \\
\hline Other manufacturing & .426 & .503 & .447 \\
\hline Electricity, gas and water supply & .252 & .566 & .713 \\
\hline Construction & .484 & .606 & .626 \\
\hline Wholesale and retail trade & .096 & .128 & .153 \\
\hline Hotels and restaurants & .008 & .010 & .012 \\
\hline Transport and storage & .152 & .173 & .159 \\
\hline Post and telecommunications & .903 & .251 & .260 \\
\hline Finance and insurance & .115 & .151 & .173 \\
\hline Real estate and Business service & .511 & .592 & .592 \\
\hline Public admin and defense & .673 & .859 & .248 \\
\hline Education and health & .124 & .122 & .116 \\
\hline Other social and personal services & .030 & .038 & .033 \\
\hline Other & .016 & .022 & .022 \\
\hline Total industry & .909 & .050 & .122 \\
\hline Sore Cary & & \\
\hline
\end{tabular}

Source: Calculated by reconstructing yearly I/O from Bank of Korea[13]

At this moment, the output increase in A industry required by a final demand unit for A industry is $r_{11}$, and the output increase in $\mathrm{A}$ industry required by a final demand unit for $\mathrm{B}$ industry is $r_{12}$. Output increase of A industry required by the final demand from each industry is presented as Row total $S_{1}$, and it is called Forward Linkage. Column total $R_{1}$ is a ripple effect to the final demand of A industry which is also called Backward Linkage.

Meanwhile, in the types of Total output multiplier, there are $(I-A)^{-1}$ type that is based on input coefficient of transaction table at producer's price in total competition import type and $\left(I-A^{d}\right)^{-1}$ type that distinguishes domestic and import $\left(A^{d}\right.$ here is imput coefficient matrix of domestic transaction table). A conventionally Total is calculated from $\left(I-A^{d}\right)^{-1},{ }^{1)}$ with

1) Some say that $\left(I-A^{d}\right)^{-1}$ is more appropriate than $(I-A)^{-1}$ because $(I-A)^{-1}$ expands Total effect more than $\left(I-A^{d}\right)^{-1}$, and contribution to production elements is same regardless of the source of production elements either in domestic or overseas. But this study used $\left(I-A^{d}\right)^{-1}$ following conventional analysis cases. For detail understanding, see Miller and Blair 
which Employment multiplier ${ }^{2)}$ appears as $\hat{l}\left(I-A^{d}\right)^{-1}$ (in here, $\hat{l}$ is employment coefficient). Total output multiplier and Employment multiplier by R\&D investment can be acquired from Modified transaction table $\widetilde{A^{d}}$, which is an exogenous specification of the $R \& D$ sector. $R \& D$ input coefficient of each industry is presented in <Table $2>$. This is drawn from Integrated transaction table at producers' price according to 2005 Constant price with modification on 28 areas. While Precision instruments, Electric \& electronic and Communication \& broadcasting had large $R \& D$ input coefficient, overall R\&D input coefficient had increased.

When looking into the impact of R\&D investment on Total output $<$ Table $3>$ by using Domestic transaction table, which is an exogenous specification R\&D sector and modified 28 areas from Domestic transaction table of Midium classification ${ }^{3)}$, this table presents production amount directly and indirectly required to satisfy a $1 \mathrm{R} \& D$ demand unit increase for a certain industry. The impact of changes in final demand of R\&D on Total output for Basic metals and Chemical industry appeared to be the highest, followed by Real estate and business service. In the trend of the impact of R\&D on Total output by industry, most of impact by R\&D demand had decreased or stagnated, while the simple average of entire economy appeared to be 1.908 in 2005, 1.893 in 2007 and 1.903 in 2009. The impact of R\&D on Employment can be acquired by comparing Employment inducement coefficient (from Employment multiplier) with Employment coefficient $\langle$ Table 4>, among which Coal and refined petroleum industry, Basic metals and Electricity, gas and water supply had large impacts. But the overall decrease of this impact is interesting. When looking into the trend of impact of changes in $R \& D$ demand on Employment, the margin of decrease of Employment inducement coefficient by R\&D demand is larger than the overall decrease margins of Employment coefficient, while the simple average of entire economy appeared to be dropping continuously as of 5.48 in 2005, 4.66 in 2007 and 4.56 in 2009.

Even though overall R\&D input coefficient by industry has increased, impact of R\&D demand on Total output has decreased or stagnated along with continuous decrease impact on Employment inducement, which raises a necessity of consideration for complementary measures on $R \& D$ in Post catching-up era. To respond on that matter, this study will focus on human resource aspect as a complementary measure for R\&D.

Table 3. Output change by the change of R\&D demand

\begin{tabular}{|l|l|l|l|}
\hline & $\mathbf{2 0 0 5}$ & $\mathbf{2 0 0 7}$ & $\mathbf{2 0 0 9}$ \\
\hline Agriculture, forestry and fisheries & 1.912 & 1.879 & 1.894 \\
\hline Mining and quarrying & 1.159 & 1.126 & 1.118 \\
\hline Food and beverages & 2.103 & 2.078 & 2.099 \\
\hline Textiles, textile and leather & 1.599 & 1.561 & 1.554 \\
\hline
\end{tabular}

[14].

2) Employment in Industry relation table means both employed and employee. Employed includes employee, self-employed and unpaid family worker. Employee is composed of regular worker, temporary worker and daily hire as wage laborers.

3) The reason to use Domestic transaction table differently from $R \& D$ input coefficient is that this study draws impact on Total requirements based on $\left(I-A^{d}\right)^{-1}$ as mentioned earlier.

\begin{tabular}{|l|l|l|l|}
\hline Wood, cork, pulp and paper & 1.998 & 2.019 & 2.061 \\
\hline Printing and publishing & 1.320 & 1.286 & 1.281 \\
\hline Coal and refined petroleum & 2.440 & 2.311 & 2.271 \\
\hline Chemicals and chemical & 3.650 & 3.575 & 3.485 \\
\hline Other non-metallic mineral & 1.441 & 1.444 & 1.429 \\
\hline Basic metals & 3.788 & 3.638 & 3.800 \\
\hline Fabricated metal & 1.817 & 1.810 & 1.759 \\
\hline Machinery & 1.693 & 1.748 & 1.757 \\
\hline Electrical equipment & 1.938 & 1.928 & 1.945 \\
\hline Optical equipment & 1.135 & 1.157 & 1.189 \\
\hline Transport equipment & 1.819 & 1.847 & 1.767 \\
\hline Other manufacturing & 1.186 & 1.244 & 1.262 \\
\hline Electricity, gas and water supply & 2.071 & 2.030 & 2.022 \\
\hline Construction & 1.187 & 1.155 & 1.144 \\
\hline Wholesale and retail trade & 2.512 & 2.484 & 2.532 \\
\hline Hotels and restaurants & 1.919 & 1.938 & 1.982 \\
\hline Transport and storage & 2.231 & 2.183 & 2.163 \\
\hline Post and telecommunications & 1.727 & 1.742 & 1.738 \\
\hline Finance and insurance & 2.280 & 2.363 & 2.543 \\
\hline Real estate and Business service & 2.975 & 2.928 & 2.929 \\
\hline Public admin and defense & 1.037 & 1.024 & 1.030 \\
\hline Education and health & 1.191 & 1.202 & 1.236 \\
\hline Other social and personal services & 1.366 & 1.446 & 1.432 \\
\hline Other & 1.920 & 1.862 & 1.854 \\
\hline Average & 1.908 & 1.893 & 1.903 \\
\hline Source: Calculated by reconstructing yearly $\mathrm{I}$ O from Bank of Korea[13] \\
\hline
\end{tabular}

Source: Calculated by reconstructing yearly I/O from Bank of Korea[13]

Table 4. Employment change by the change of R\&D demand

\begin{tabular}{|c|c|c|c|c|c|c|c|c|c|}
\hline & \multicolumn{3}{|c|}{$\begin{array}{l}\text { Employment } \\
\text { coefficient }\end{array}$} & \multicolumn{3}{|c|}{$\begin{array}{c}\text { Employment } \\
\text { inducement } \\
\text { coefficient }\end{array}$} & \multicolumn{3}{|c|}{$\begin{array}{c}\text { Employment } \\
\text { inducement } \\
\text { coefficient/ } \\
\text { Employment } \\
\text { coefficient }\end{array}$} \\
\hline & 2005 & 2007 & 2009 & 2005 & 2007 & 2009 & 2005 & 2007 & 2009 \\
\hline $\begin{array}{l}\text { Agriculture, } \\
\text { forestry and } \\
\text { fisheries }\end{array}$ & .0426 & . 0393 & .0352 & . 0536 & .0496 & .0450 & 1.26 & 1.26 & 1.28 \\
\hline $\begin{array}{l}\text { Mining and } \\
\text { quarrying }\end{array}$ & . 0054 & .0058 & .0056 & .0062 & .0063 & .0061 & 1.15 & 1.10 & 1.10 \\
\hline $\begin{array}{l}\text { Food and } \\
\text { beverages }\end{array}$ & . 0039. & . 0037. & . 0035 & .0200 & .0197 & . 0193. & 5.15 & 5.26 & 5.54 \\
\hline $\begin{array}{l}\text { Textiles, textile and } \\
\text { leather }\end{array}$ & .0086 & . 0079. & .0078 & 要. .139 & .0125 & .0123 & 1.62 & 1.58 & 1.57 \\
\hline $\begin{array}{l}\text { Wood, cork, pulp } \\
\text { and paper }\end{array}$ & .0052 & . 0048 & .0047 & .0133 & .0131 & . 0128. & 2.57 & 2.71 & 2.73 \\
\hline $\begin{array}{l}\text { Printing and } \\
\text { publishing }\end{array}$ & .0089 & . 0111. & .0098 & . 0119. & .0140 & .0124 & 1.33 & 1.26 & 1.27 \\
\hline $\begin{array}{l}\text { Coal and refined } \\
\text { petroleum }\end{array}$ & .0002 & .0002 & .0002 & .0132 & .0112 & . 0106 & 72.49 & 51.28 & 47.69 \\
\hline $\begin{array}{l}\text { Chemicals and } \\
\text { chemical }\end{array}$ & .0027 & . 0025 & .0024 & .0248 & .0229 & . 0215. & 9.16 & 9.32 & 8.87 \\
\hline $\begin{array}{l}\text { Other non-metallic } \\
\text { mineral }\end{array}$ & .0043 & .0038 & .0036 & .0072 & .0066 & .0062 & 1.67 & 1.74 & 1.73 \\
\hline Basic metals & .0010 & .0010 & .0011 & .0149 & .0135 & .0151 & 14.70 & 12.95 & 13.62 \\
\hline Fabricated metal & .0066 & .0064 & .0071 & .0124 & .0119 & .0123 & 1.87 & 1.86 & 1.75 \\
\hline Machinery & .0050 & .0042 & .0047 & .0095 & .0088 & .0094 & 1.92 & 2.07 & 2.00 \\
\hline $\begin{array}{l}\text { Electrical } \\
\text { equipment }\end{array}$ & .0032 & . 0025 & .0021 & . 0092 & .0078 & .0072 & 2.84 & 3.17 & 3.47 \\
\hline Optical equipment & .0072 & .0056 & .0055 & .0081 & .0066 & .0067 & 1.13 & 1.18 & 1.22 \\
\hline $\begin{array}{l}\text { Transport } \\
\text { equipment }\end{array}$ & . 0029. & . 0027. & .0030 & .0082 & .0081 & . 0081 & 2.87 & 3.00 & 2.67 \\
\hline $\begin{array}{l}\text { Other } \\
\text { manufacturing }\end{array}$ & .0081 & . 00068 & .0069 & .0096 & .0087 & . 0090. & 1.19 & 1.28 & 1.30 \\
\hline $\begin{array}{l}\text { Electricity, gas and } \\
\text { water supply }\end{array}$ & .0015 & . 0014 & .0014 & .0096 & .0086 & . & 6.44 & 6.04 & 6.22 \\
\hline Construction & .0105 & $\begin{array}{l}.0107 \\
\end{array}$ & .0103 & .0121 & .0120 & .0116 & 1.16 & 1.12 & 1.13 \\
\hline $\begin{array}{l}\text { Wholesale and } \\
\text { retail trade }\end{array}$ & .0254 & . 0246. & .0261 & .0386 & .0365 & . 0382 & 1.52 & 1.48 & 1.46 \\
\hline $\begin{array}{l}\text { Hotels and } \\
\text { restaurants }\end{array}$ & . 0247. & . & .0235 & .0291 & .0281 & . 0280. & 1.18 & 1.18 & 1.19 \\
\hline
\end{tabular}




\begin{tabular}{|l|c|c|c|c|c|c|c|c|c|}
\hline $\begin{array}{l}\text { Transport and } \\
\text { storage }\end{array}$ & .0121 & .0112 & .0114 & .0226 & .0210 & .0209 & 1.86 & 1.87 & 1.84 \\
\hline $\begin{array}{l}\text { Post and } \\
\text { telecommunications }\end{array}$ & .0031 & .0029 & .0027 & .0095 & .0094 & .0093 & 3.06 & 3.17 & 3.43 \\
\hline $\begin{array}{l}\text { Finance and } \\
\text { insurance }\end{array}$ & .0062 & .0055 & .0052 & .0177 & .0169 & .0184 & 2.84 & 3.10 & 3.54 \\
\hline $\begin{array}{l}\text { Real estate and } \\
\text { Business service }\end{array}$ & .0071 & .0069 & .0085 & .0263 & .0249 & .0265 & 3.70 & 3.59 & 3.13 \\
\hline $\begin{array}{l}\text { Public admin and } \\
\text { defense }\end{array}$ & .0102 & .0095 & .0101 & .0104 & .0097 & .0103 & 1.03 & 1.02 & 1.02 \\
\hline $\begin{array}{l}\text { Education and } \\
\text { health }\end{array}$ & .0160 & .0163 & .0163 & .0180 & .0183 & .0186 & 1.12 & 1.12 & 1.14 \\
\hline $\begin{array}{l}\text { Other social and } \\
\text { personal services }\end{array}$ & .0176 & .0166 & .0175 & .0208 & .0202 & .0208 & 1.19 & 1.21 & 1.19 \\
\hline Other & .0093 & .0088 & .0087 & .0167 & .0158 & .0157 & 5.48 & 4.66 & 4.56 \\
\hline Average
\end{tabular}

Source: Calculated by reconstructing yearly I/O from Bank of Korea[13]

\section{CONNECTIVITY BETWEEN UNIVERSITY MAJOR AND WORK: FOCUSING ON WAGE FUNCTION}

This chapter focuses on Human Resource as a complementary measure for $\mathrm{R} \& \mathrm{D}$, while analyzing the wage of new university graduate, compatibility of major-industry and usefulness of majored curriculum at the level of 28 industry classifications mentioned earlier. Data used for that purpose includes the wage information ${ }^{4)}$ of 10,636 persons from 2008 survey on 2005 graduates in Graduates Occupational Mobility Survey (GOMS) ${ }^{5}$, and 7,908 persons with income among 2007 university graduates surveyed on 2010. Also grade data which is a critical factor in wage function estimation of university graduate is combined together. Grade data of individual ${ }^{6)}$ was drawn from internal data of Jinhaksa for nationwide yearly grade data by university \& department. This study used 2001 entry grade data for 2005 graduates and 2003 data for 2007 graduates. Grade data employed average score of each university and department calculated as 100 percentile of nationwide score, and included distinction of campus such as main and branch campuses. ${ }^{7)}$

4) It should be income instead of wage in strict sense because it includes selfemployed beside of employee, but it became wage information because it did not include financial earnings. Meanwhile, the education division of university in this study is distinguished from separate Educational universities. The average monthly income of 3rd year Educational university graduate in 2010 was 2.21 million won, whereas that of 3rd year Vocational college graduate was 2.02 million won.

5) Refer to http://survey.keis.or.kr for introduction and data of Graduates Occupational Mobility Survey (GOMS)[15].

6) Dr. Yim, Un's help was absolutely critical in grade data utilizing and for detailed items of grade data, refer to the chapter 7 of 5 Socio-economic achievement \& limitation of higher education $\lrcorner$ by Kim et al.[16]. In the process of using grade data, some universities without the grades of departments were eliminated, and therefore, the sample size of Engineering in Table 5 and Table 6 , which had not use grade data, doesn't match with the sample size of Engineering in Table 7, which had used grade data. But the average income of total sample by school without grade data doesn't have much difference with the average income of reduced samples by school. And the estimated result of wage function without grade data is consistent in overall aspect with the estimated result of wage function with grade data excluding the items for grade data.

7) Some universities' departments in the graduates' departments in GOMS are not concurrent with the departments in the grade data provided by Jinjaksa, which cases are regarded as related department or department in similar school.
Table 5. Average monthly income (After 3 years from graduation)

\begin{tabular}{|c|c|c|c|c|}
\hline \multirow[b]{3}{*}{$\begin{array}{l}\text { Major } \\
\text { Filed }\end{array}$} & & & (Unit: pe & on, $10 \mathrm{k}$ wor \\
\hline & \multicolumn{2}{|c|}{2008} & \multicolumn{2}{|c|}{2010} \\
\hline & $\begin{array}{c}\text { Sample } \\
\text { size }\end{array}$ & $\begin{array}{c}\text { Average } \\
\text { monthly } \\
\text { income }\end{array}$ & $\begin{array}{c}\text { Sample } \\
\text { size }\end{array}$ & $\begin{array}{l}\text { Average } \\
\text { monthly } \\
\text { income }\end{array}$ \\
\hline Liberal arts & 1,278 & 197.8 & 1,066 & 205.9 \\
\hline Social science & 2,763 & 228.9 & 1,751 & 230.9 \\
\hline Education & 589 & 199.7 & 532 & 203.5 \\
\hline Engineering & 3,332 & 245.1 & 2,228 & 251.6 \\
\hline Science & 1,482 & 199.7 & 1,194 & 220.6 \\
\hline Medical & 397 & 249.9 & 336 & 260.5 \\
\hline Art \& athletic & 795 & 186.1 & 801 & 184.6 \\
\hline Total & 10,636 & 222.1 & 7,908 & 226.5 \\
\hline
\end{tabular}

The average monthly income of 3rd-year university graduate came out to be 2.221 million won in 2008 and 2.265 million won in 2010. Against that, to identify the effect by grade, gender, major, enterprise size and industry, the estimated results of wage functions are presented in table 6 . While the wage effect of grade is significant, all the school name value effects are controlled in wage function estimation. Female has significantly lower wage than male, and as the enterprise size is larger, the wage was higher. Wage effect by major also displays significant result except Social science division. When comparing the wage effect by industry with Machinery industry as the basis, Finance $\&$ insurance has the highest effect. Coal and refined petroleum, Electricity, gas and water supply, Electrical equipment and Transport equipment had significantly higher wage effects than Machinery industry, while Education $\&$ health service, Public administration, Social \& personal service and Food \& lodging had significantly lower wage effects than Machinery industry.

The interesting thing in this study is the effects of 'compatibility between work and major' and 'usefulness between work and major ${ }^{8)}$ to wage, rather than wage effect of major or industry itself. 'Compatibility between work and major' had decreased in 2010 from 2008 but instead, the effect of 'usefulness between work and major' to wage became significant. It is necessary to analyze more on the effects of 'compatibility between work and major' and 'usefulness between work and major' to wage by major.

To follow the purpose of this study, rather than targeting all the departments, this study will focus on Engineering school. Because Natural science departments such as Physics and Chemistry have not high direct relationship between major and work except some part, ${ }^{9)}$ this study will focus on the limited results in Engineering school. ${ }^{10)}$ (A) Major dummy analysis displays estimated wage function results of newly employed Engineering school graduate (3 years after graduation), while

\footnotetext{
8) The case of answering yes on usefulness between work and major among the cases of yes answer on usefulness between work and major is 1 , and all others are 0 .

9) This can be verified in a separate analysis.

10) Some difficult to include departments into major classification in Engineering school. And used modified sample with 2,781 persons (83\%) among 3332 persons of 2008 Engineering school wage analysis sample, and 1783 persons (80\%) among 1783 persons of 2010 Engineering school sample.
} 
(B) work-major compatibility analysis was estimated by having major compatibility as a variable instead of major dummy and processing the work-major usefulness with separate dummy variable. (C) Work-major usefulness analysis employed major usefulness by major as a variable. ${ }^{11)}$

Table 6. Estimated wage functions of newly employed (After 3 years from graduation)

\begin{tabular}{|c|c|c|c|c|c|}
\hline \multirow{2}{*}{\multicolumn{2}{|c|}{$\begin{array}{l}\text { Independent variable: } \\
\text { Log(Average monthly income) }\end{array}$}} & \multicolumn{2}{|c|}{2008} & \multicolumn{2}{|c|}{2010} \\
\hline & & \multicolumn{2}{|c|}{$\begin{array}{l}\text { Estimated coefficient } \\
\qquad(\operatorname{Pr}>|\mathrm{t}|)\end{array}$} & \multicolumn{2}{|c|}{$\begin{array}{l}\text { Estimated coefficient } \\
\qquad(\operatorname{Pr}>|t|)\end{array}$} \\
\hline \multicolumn{2}{|c|}{ Constant term } & 5.508 & $<.0001 * * *$ & 5.541 & $<.0001 * * *$ \\
\hline \multicolumn{2}{|c|}{ Gender $($ Male $=0$ ) } & -0.179 & $<.0001 * * *$ & -0.148 & $<.0001 * * *$ \\
\hline \multirow{6}{*}{$\begin{array}{l}\text { School } \\
\text { (Engineering } \\
=0 \text { ) }\end{array}$} & Liberal arts & -0.042 & $0.002 * * *$ & -0.064 & $<.0001 * * *$ \\
\hline & Social science & 0.011 & 0.282 & -0.012 & 0.302 \\
\hline & Education & 0.140 & $<.0001 * * *$ & 0.062 & $0.001 * * *$ \\
\hline & Science & -0.058 & $<.0001 * * *$ & -0.034 & $0.009 * * *$ \\
\hline & Medical & 0.241 & $<.0001 * * *$ & 0.223 & $<.0001 * * *$ \\
\hline & Art \& athletic & -0.076 & $<.0001 * * *$ & -0.133 & $<.0001 * * *$ \\
\hline \multirow{21}{*}{$\begin{array}{l}\text { Industry } \\
\text { (Machinery } \\
\text { industry=0) }\end{array}$} & $\begin{array}{l}\text { Agriculture, forestry } \\
\text { and fisheries }\end{array}$ & -0.043 & 0.649 & -0.005 & 0.947 \\
\hline & Mining and quarrying & 0.117 & 0.449 & 0.156 & 0.430 \\
\hline & Food and beverages & 0.002 & 0.964 & -0.069 & $0.087^{*}$ \\
\hline & $\begin{array}{l}\text { Textiles, textile and } \\
\text { leather }\end{array}$ & -0.051 & 0.207 & -0.049 & 0.187 \\
\hline & $\begin{array}{l}\text { Wood, cork, pulp and } \\
\text { paper }\end{array}$ & -0.020 & 0.756 & -0.022 & 0.816 \\
\hline & $\begin{array}{l}\text { Printing and } \\
\text { publishing }\end{array}$ & -0.048 & 0.738 & -0.182 & $0.058^{*}$ \\
\hline & $\begin{array}{l}\text { Coal and refined } \\
\text { petroleum }\end{array}$ & 0.192 & $0.015 * *$ & 0.143 & $0.100^{*}$ \\
\hline & $\begin{array}{l}\text { Chemicals and } \\
\text { chemical }\end{array}$ & 0.062 & $0.018 * *$ & 0.031 & 0.235 \\
\hline & $\begin{array}{l}\text { Other non-metallic } \\
\text { mineral }\end{array}$ & 0.017 & 0.791 & 0.027 & 0.665 \\
\hline & Basic metals & 0.008 & 0.892 & 0.101 & $0.035^{* *}$ \\
\hline & Fabricated metal & -0.079 & $0.072 *$ & -0.080 & $0.093 *$ \\
\hline & Machinery & 0.061 & $0.005 * * *$ & 0.072 & $0.004 * * *$ \\
\hline & Electrical equipment & 0.014 & 0.773 & -0.055 & 0.186 \\
\hline & Optical equipment & 0.070 & $0.010 * * *$ & 0.082 & $0.002 * * *$ \\
\hline & Transport equipment & -0.065 & 0.238 & -0.064 & 0.326 \\
\hline & Other manufacturing & 0.138 & $0.000 * * *$ & 0.130 & $0.003 * * *$ \\
\hline & $\begin{array}{l}\text { Electricity, gas and } \\
\text { water supply }\end{array}$ & 0.049 & $0.040 * *$ & 0.031 & 0.206 \\
\hline & Construction & 0.050 & $0.019 * *$ & 0.023 & 0.272 \\
\hline & $\begin{array}{l}\text { Wholesale and retail } \\
\text { trade }\end{array}$ & -0.098 & $0.003 * * *$ & -0.096 & $0.008 * * *$ \\
\hline & $\begin{array}{l}\text { Hotels and } \\
\text { restaurants }\end{array}$ & 0.085 & $0.003 * * *$ & 0.059 & $0.068^{*}$ \\
\hline & Transport and storage & -0.016 & 0.651 & 0.051 & 0.196 \\
\hline
\end{tabular}

11) In the process of setting major usefulness by major as a variable, when estimating major compatibility by processing with dummy variable, no meaning result appeared. Therefore, only the analysis result that removed that at final stage is presented. With a same reason, major dummy also presents the result after removing (A) work-major compatibility analysis (B) work-major usefulness analysis, which displayed no meaningful result in analysis process. Meanwhile, the effects of industry and enterprise size were omitted because they were similar with the wage function estimate result of entire new employed in the earlier part.

\begin{tabular}{|c|c|c|c|c|c|}
\hline & \begin{tabular}{|l} 
Post and \\
telecommunications
\end{tabular} & 0.253 & $<.0001 * * *$ & 0.202 & $<.0001 * * *$ \\
\hline & $\begin{array}{l}\text { Finance and } \\
\text { insurance }\end{array}$ & -0.013 & 0.480 & -0.007 & 0.686 \\
\hline & $\begin{array}{l}\text { Real estate and } \\
\text { Business service }\end{array}$ & -0.217 & $<.0001 * * *$ & -0.198 & $<.0001 * * *$ \\
\hline & $\begin{array}{l}\text { Public admin and } \\
\text { defense }\end{array}$ & -0.252 & $<.0001 * * *$ & -0.222 & $<.0001^{* * *}$ \\
\hline & Education and health & -0.164 & $<.0001^{* * *}$ & -0.177 & $<.0001 * * *$ \\
\hline \multirow{4}{*}{$\begin{array}{l}\text { Enterprise } \\
\text { size } \\
(\text { Over } \\
300=0)\end{array}$} & $1 \sim 4$ & -0.354 & $<.0001 * * *$ & -0.204 & $<.0001 * * *$ \\
\hline & $5 \sim 9$ & -0.278 & $<.0001 * * *$ & -0.207 & $<.0001 * * *$ \\
\hline & $10 \sim 99$ & -0.147 & $<.0001 * * *$ & -0.130 & $<.0001 * * *$ \\
\hline & $100 \sim 299$ & -0.106 & $<.0001 * * *$ & -0.090 & $<.0001^{* * *}$ \\
\hline \multicolumn{2}{|c|}{$\begin{array}{l}\text { Compatibility between work-major } \\
(\text { Not compatible }=0)\end{array}$} & 0.083 & $<.0001^{* * *}$ & 0.048 & $<.0001 * * *$ \\
\hline \multicolumn{2}{|c|}{$\begin{array}{l}\text { Usefulness between work-major } \\
(\text { Not useful }=0)\end{array}$} & 0.014 & 0.112 & 0.017 & $0.058^{*}$ \\
\hline \multicolumn{2}{|l|}{ F Value } & \multicolumn{2}{|c|}{117.060} & \multicolumn{2}{|c|}{72.180} \\
\hline \multicolumn{2}{|l|}{$\operatorname{Pr}>\mathrm{F}$} & \multicolumn{2}{|c|}{$<.0001^{* * *}$} & \multicolumn{2}{|c|}{$<.0001 * * *$} \\
\hline \multicolumn{2}{|l|}{ Adj R-Sq } & \multicolumn{2}{|c|}{0.299} & \multicolumn{2}{|c|}{0.260} \\
\hline
\end{tabular}

Note: $\operatorname{Pr}>|\mathrm{t}|<0.01$ is ***, $\operatorname{Pr}>|\mathrm{t}|<0.05$ is **, $\operatorname{Pr}>|\mathrm{t}|<0.1$ is *

Firstly, (A) when considering major dummy (Mechanical engineering as basis), work-major usefulness and work-major compatibility altogether in major dummy analysis (standard row), except Chemical engineering, wage difference by major was shown significantly. The wage level by major in 2010 displays the order of Mechanical > Electric \& electronics > Source Material $>$ Civil engineering $>$ Construction from the highest. More interesting wage effects of work-major compatibility and work-major usefulness had positive effect of work-major compatibility in 2008 but significantly positive effect of work-major usefulness in 2010.

(B) In the result of major compatibility analysis by detailed major, major compatibility had positive effect on wage in Civil engineering, Mechanical engineering, Electric \& electronics engineering, Computer science and Chemical engineering in 2008, while no significant major compatibility effect in overall aspect. In 2010, work-major usefulness was not statistically significant for all the majors, while overall major usefulness had positive effect. (C) In the result of major usefulness analysis by detailed major, only the major usefulness effect of Mechanical engineering had positive effect in 2008. In 2010 also, only the major usefulness effect of Mechanical engineering had positive effect, with seemingly increased effect from 2008, all other majors had not statistically significant effect of major usefulness by detailed major.

Even though influencing factors to wage in the detailed majors of Engineering school is being shifted to work-major usefulness from work-major compatibility, the effect of workmajor usefulness in detailed major is being delayed. ${ }^{12)}$ When wage is regarded as representative index for productivity, the wage effect of work-major usefulness can be an effect for productivity of work-major usefulness, and the improvement for work-major usefulness is being stagnated. It can be interpreted as a retreat in overall aspect of connectivity between

12) Analysis result in above and its interpretation are in rough status. In relation with that, more strict analysis with from detailed research remains as following study subject. 
Human Resource and work.

Table 7. Major compatibility \& usefulness effects of New Engineering school graduate employed (3 years after graduation)

\begin{tabular}{|c|c|c|c|c|c|c|c|c|c|c|c|c|c|}
\hline \multirow{4}{*}{\multicolumn{2}{|c|}{\begin{tabular}{|l} 
\\
Constant term
\end{tabular}}} & \multicolumn{4}{|c|}{ (A) Major dummy (Mechanical=0) } & \multicolumn{4}{|c|}{$\begin{array}{l}\text { (B) Major compatibility dummy by major } \\
\text { (No compatibility=0) }\end{array}$} & \multicolumn{4}{|c|}{$\begin{array}{l}\text { (C) Major usefulness dummy by major } \\
\text { (No usefulness }=0 \text { ) }\end{array}$} \\
\hline & & \multicolumn{2}{|c|}{2008} & \multicolumn{2}{|c|}{2010} & \multicolumn{2}{|c|}{2008} & \multicolumn{2}{|c|}{2010} & \multicolumn{2}{|c|}{2008} & \multicolumn{2}{|c|}{2010} \\
\hline & & \multicolumn{2}{|c|}{$\begin{array}{l}\text { Estimated coefficient } \\
\qquad(\operatorname{Pr}>|t|)\end{array}$} & \multicolumn{2}{|c|}{$\begin{array}{l}\text { Estimated coefficient } \\
\qquad(\operatorname{Pr}>|t|)\end{array}$} & \multicolumn{2}{|c|}{$\begin{array}{c}\text { Estimated coefficient } \\
(\operatorname{Pr}>|t|)\end{array}$} & \multicolumn{2}{|c|}{$\begin{array}{c}\text { Estimated coefficient } \\
(\operatorname{Pr}>|t|)\end{array}$} & \multicolumn{2}{|c|}{\begin{tabular}{|c|} 
Estimated coefficient \\
$(\operatorname{Pr}>|t|$
\end{tabular}} & \multicolumn{2}{|c|}{$\begin{array}{l}\text { Estimated coefficient } \\
(\operatorname{Pr}>|t|)\end{array}$} \\
\hline & & 4.672 & $<.0001 * * *$ & 5.282 & $<.0001 * * *$ & 4.640 & $<.0001 * * *$ & 5.288 & $<.0001 * * *$ & 4.664 & $<.0001 * * *$ & 5.296 & $<.0001 * * *$ \\
\hline \multicolumn{2}{|c|}{ Grade } & 0.002 & $<.0001^{* * *}$ & 0.001 & $<.0001 * * *$ & 0.002 & $<.0001^{* * *}$ & 0.001 & $<.0001 * * *$ & 0.003 & $<.0001^{* * *}$ & 0.001 & $<.0001 * * *$ \\
\hline \multicolumn{2}{|c|}{ Gender $($ Male $=0)$} & -0.104 & $<.0001^{* * * *}$ & -0.123 & $<.0001 * * *$ & -0.107 & $<.0001^{* * *}$ & -0.123 & $<.0001^{* * * *}$ & -0.110 & $<.0001^{* * *}$ & -0.124 & $<.0001^{* * *}$ \\
\hline \multirow{4}{*}{$\begin{array}{l}\mathrm{M} \\
\mathrm{a} \\
\mathrm{j} \\
\mathrm{o} \\
\mathrm{r} \\
\mathrm{r}\end{array}$} & Architectural & -0.047 & $0.065^{*}$ & -0.044 & $0.086^{*}$ & 0.041 & 0.116 & -0.032 & 0.255 & 0.012 & 0.636 & 0.023 & $<.0001^{* * *}$ \\
\hline & Civil engineering & -0.023 & 0.357 & -0.024 & 0.392 & 0.051 & $0.054 *$ & -0.015 & 0.630 & 0.013 & 0.624 & 0.023 & 0.494 \\
\hline & Mechanical & & & & & 0.073 & $0.002^{* * *}$ & 0.023 & 0.373 & 0.022 & 0.344 & 0.038 & 0.528 \\
\hline & Electric/electronics & -0.030 & 0.260 & -0.042 & 0.136 & 0.045 & $0.032 * *$ & -0.023 & 0.313 & 0.004 & 0.839 & 0.006 & 0.257 \\
\hline \multirow{3}{*}{ e } & Source/material & -0.037 & $0.054 *$ & 0.014 & 0.466 & 0.013 & 0.660 & -0.025 & 0.435 & -0.017 & 0.595 & 0.018 & 0.838 \\
\hline & $\begin{array}{l}\text { Computer/ } \\
\text { telecommunication }\end{array}$ & 0.039 & 0.188 & 0.004 & 0.902 & 0.056 & $0.004 * * *$ & 0.016 & 0.439 & 0.029 & $0.089^{*}$ & 0.030 & 0.678 \\
\hline & Chemical & 0.039 & 0.188 & 0.004 & 0.902 & 0.121 & $0.000 * * *$ & 0.014 & 0.682 & 0.092 & $0.014 * *$ & 0.058 & 0.218 \\
\hline \multicolumn{2}{|c|}{$\begin{array}{l}\text { Work-major usefulness } \\
\text { (No usefulness }=0 \text { ) }\end{array}$} & -0.001 & 0.915 & 0.026 & $0.079 *$ & -0.002 & 0.894 & 0.031 & $0.032 * *$ & & & & \\
\hline \multicolumn{2}{|c|}{$\begin{array}{l}\text { Work-major compatibility } \\
\text { (No compatibility }=0 \text { ) }\end{array}$} & 0.058 & $0.001 * * *$ & 0.010 & 0.584 & & & & & & & & \\
\hline \multicolumn{2}{|c|}{ F Value } & \multicolumn{2}{|c|}{37.90} & \multicolumn{2}{|c|}{19.54} & \multicolumn{2}{|c|}{37.82} & \multicolumn{2}{|c|}{19.47} & \multicolumn{2}{|c|}{38.26} & \multicolumn{2}{|c|}{19.75} \\
\hline \multicolumn{2}{|c|}{$\operatorname{Pr}>\mathrm{F}$} & \multicolumn{2}{|c|}{$<.0001 * * *$} & \multicolumn{2}{|c|}{$<.0001 * * *$} & \multicolumn{2}{|c|}{$<.0001 * * *$} & $<.00$ & $01 * * *$ & $<.000$ & 1 *** & $<.000$ & 1 *** \\
\hline & $\mathrm{R}-\mathrm{Sq}$ & & 35 & & 28 & & 0.35 & & 0.28 & & 0.35 & & 0.28 \\
\hline
\end{tabular}

Note: $\operatorname{Pr}>|\mathrm{t}|<0.01$ is ***, $\operatorname{Pr}>|\mathrm{t}|<0.05$ is **, $\operatorname{Pr}>|\mathrm{t}|<0.1$ is *

\section{ISSUE OF CO-ORDINATION BETWEEN R\&D AND HUMAN RESOURCE}

Since the assertion, saying that technological development and workforce (in skill level aspect) are complementary to each other, was raised in the complementarity hypothesis of Griliches[17], many empirical analyses for skill-based technology has been studied[18]. Also there is adaptation hypothesis by Nelson and Phelps[19], in which a human capital in appropriate level precedes to adoption of new technology. That is a classic discussion on the relation between technological development and human capital along with Griliches' complementarity hypothesis.

On the basis of these hypotheses, it can be predicted that R\&D input should co-ordinate with outstanding human resources for improved achievement. Therefore, in response to R\&D input increase, utilizing and recruiting outstanding human resources should be planned. For that matter, this chapter will review 'Connectivity with work' of new workforce by wage level and industry for influx of new outstanding human resources by industry in the aspect of co-ordination between $\mathrm{R} \& \mathrm{D}$ and appropriate human capital utilization.

Before using Graduates Occupational Mobility Survey (GOMS) data, reviewing the changing trend of employee average wage by industry on the constant price of 2005 by using Input-Output table and attached Employment table, is useful for following analysis. Analysis on the difference in changing pattern by industry and difference in rate of change should be reviewed separately. In this chapter, the average figure in 3 period of average wage of employee by industry is presented in the 4-quadrant of [Picture 1] along with the average figure of R\&D input rate by industry in 3 period. ${ }^{13)}$

The 1st quadrant displays above the average employee average wage and R\&D input rate, and the industries in this area have high $R \& D$ input along with easy recruiting of quality HR. Chemicals and chemical (CC), Electrical equipment (EE), Transportation equipment(TE), Electricity, gas and water supply (GW) and Post and telecommunications (PT) belong to this area. The 2nd quadrant has high R\&D input but lower employee average wage than entire industry average. This is a area with difficulty for securing quality HR compared to R\&D, having a possibility of discordance between technology and HR. Precision instruments belong to this area. The 3rd quadrant has low R\&D input and low attraction to quality HR, being interpreted as relatively lagged behind area in technological

\footnotetext{
13) When comparing the yearly average employee wage and R\&D input rate by industry, Electrical equipment(EE), Electricity, gas and water supply(GW) and Post and telecommunications (PT) displays rightward migration (average wage increase), while Other social and personal services (OS) displays upward migration ( $\& \& D$ input rate increase).
} 
innovation aspect. Agriculture, forestry and fisheries (AF), Food and beverages (FB), Textiles, textile and leather (TT), Printing and publishing (PP), Fabricated metal (FM), Other manufacturing (OM), Construction (CT), Wholesale and retail trade (WR), Hotels and restaurants (HR), Transport and storage (TS), Real estate and Business service (RB) and Other social and personal services (OS) belong to this area. The 4th quadrant has low R\&D input but high average employee wage, having possibility of low efficiency on Human Resource, which has another meaning of possibility for discordance between technology and HR. Mining and quarrying (MQ), Wood, cork, pulp and paper (WP), Coal and refined petroleum (CP), Other non-metallic mineral (NM), Basic Metals (BM), Financial and insurance (FI), Public admin and defense (PA) and Education and health $(\mathrm{EH})$ belong to this area.

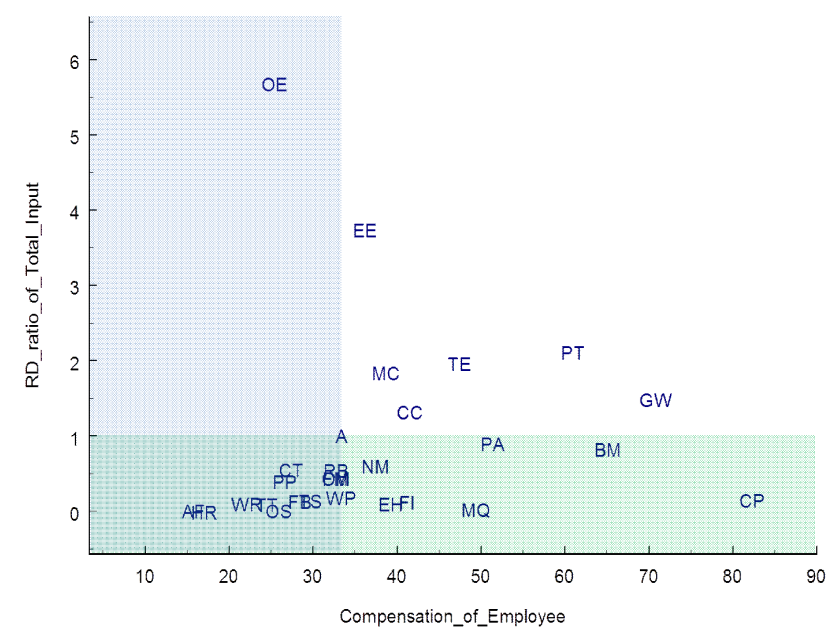

Average wage of employee and $R \& D$ input ratio

With this distinction of 4-quadrants, an interpretation for that is made by comparing the average monthly wage of newly employed university graduate in different time period which was derived from GOMS data $<$ Table $8>$. In the 1 st quadrant, except Post and telecommunications (PT), wage increase rate is similar or lower than the average, rendering suppressed influx of quality HR. Especially the wage of Chemicals and chemical (CC) has decreased. In the 2nd quadrant, Optical equipment (OE) has wage decrease with worsened inflow of quality HR. 3rd quadrant also displays low wage in overall, with suppressed was increase below the average. The 4th quadrant displays getting higher overall wage level which is already higher than other areas (but Coal and refined petroleum (CP) displays wage decrease), making its Human Resource efficiency doubtful from the perspective of entire economy.

Table 8. Classification of Newly employed university graduate(within 3 years from graduation) 's wage and R\&D input ratio on Fig. 1

\begin{tabular}{|l|l|c|c|c|}
\hline classification & $\begin{array}{l}\text { IO 28 industry } \\
\text { classification }\end{array}$ & $\mathbf{2 0 0 8}$ & $\mathbf{2 0 1 0}$ & $\begin{array}{c}\text { Average } \\
\text { yearly } \\
\text { increase } \\
\text { rate }\end{array}$ \\
\hline \multirow{2}{*}{ 1st quadrant } & $\begin{array}{l}\text { Chemicals and chemical } \\
(\mathrm{CC})\end{array}$ & 251.7 & 248.1 & -0.007 \\
\cline { 2 - 5 } & Machinery (MC) & 238.7 & 240.7 & 0.004 \\
\hline
\end{tabular}

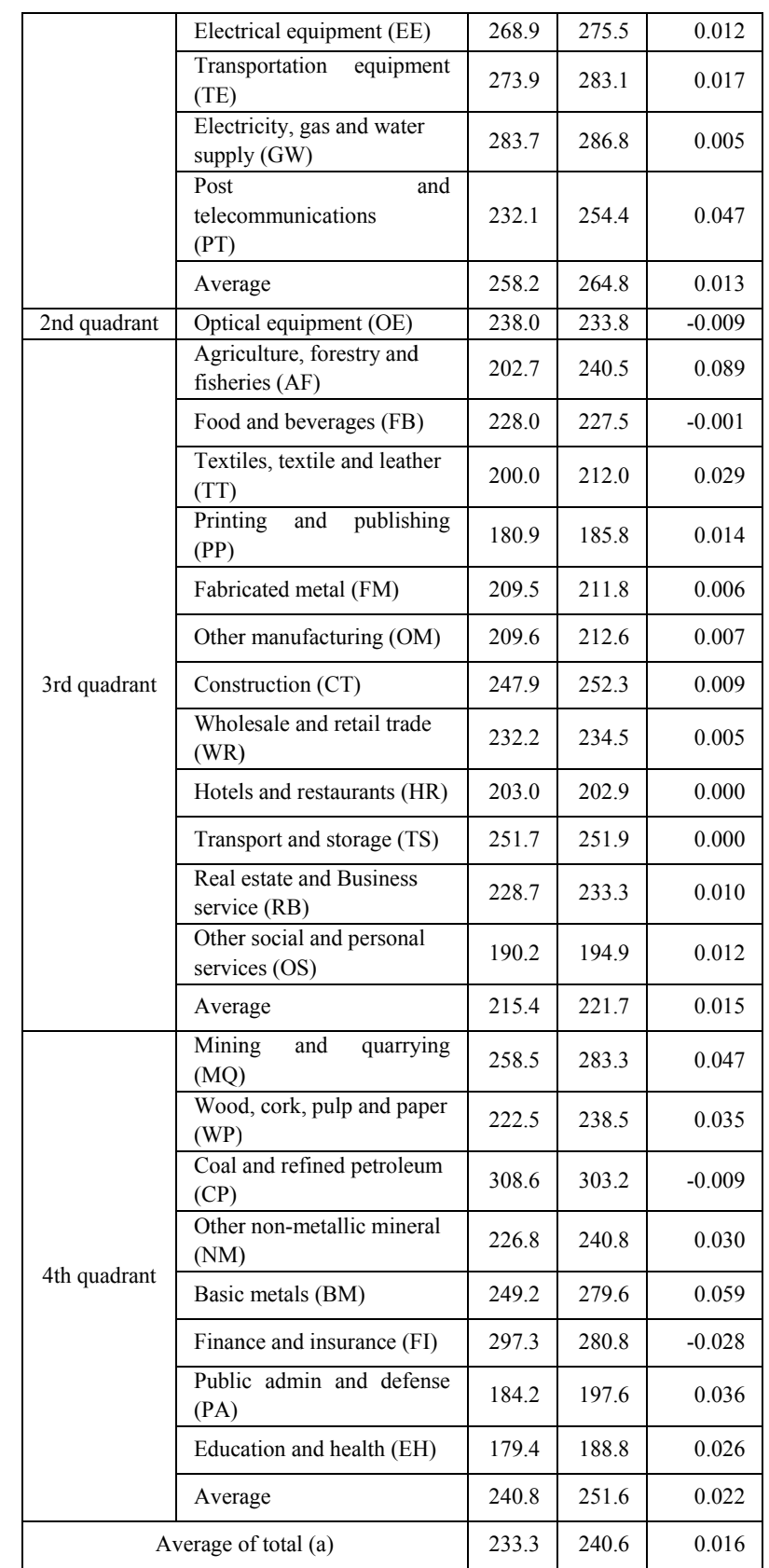

Source: Drawn from GOMS 2005-3, 2007-3 data

In 'Work-major Compatibility' ${ }^{14)}$ The 1st quadrant displays major compatibility of average 0.8 in 2008 and average 0.76 in 2010 , which is high major compatibility but receding in overall major compatibility. Major compatibility has grown only in Electrical equipment industry. Optical equipment industry in the 2nd quadrant displays increase in major compatibility with high major compatibility of 0.79 in 2008 and 0.84 in 2010 . 3rd quadrant displays not high major compatibility in overall. Its major compatibility had increased from average 0.67 in 2008 to average 0.69 in 2010 but in major compatibility of detailed major had decreased. 4th quadrant displays generally high major compatibility and in increasing trend but some industries with lower major compatibility had decreased in

14) In range of Maximum is 1 and that of Minimum is 0. 
major compatibility.

Table 9. 'Work-major compatibility' of newly employed university graduate (Within 3 years from graduation)

\begin{tabular}{|c|c|c|c|c|}
\hline classification & IO 28 industry lassification & 2008 & 2010 & $\begin{array}{c}\text { annual } \\
\text { growth } \\
\text { rate }\end{array}$ \\
\hline \multirow{7}{*}{ 1st quadrant } & $\begin{array}{l}\text { Chemicals and chemical } \\
\text { (CC) }\end{array}$ & 0.84 & 0.71 & -0.083 \\
\hline & Machinery (MC) & 0.77 & 0.75 & -0.013 \\
\hline & Electrical equipment (EE) & 0.82 & 0.83 & 0.009 \\
\hline & $\begin{array}{l}\text { Transportation equipment } \\
\text { (TE) }\end{array}$ & 0.76 & 0.74 & -0.015 \\
\hline & $\begin{array}{l}\text { Electricity, gas and water } \\
\text { supply (GW) }\end{array}$ & 0.88 & 0.85 & -0.013 \\
\hline & $\begin{array}{l}\text { Post and telecommunications } \\
\text { (PT) }\end{array}$ & 0.73 & 0.69 & -0.028 \\
\hline & Average & 0.80 & 0.76 & -0.024 \\
\hline 2nd quadrant & Optical equipment (OE) & 0.79 & 0.84 & 0.037 \\
\hline \multirow{13}{*}{ 3rd quadrant } & $\begin{array}{l}\text { Agriculture, forestry and } \\
\text { fisheries (AF) }\end{array}$ & 0.63 & 0.82 & 0.144 \\
\hline & Food and beverages (FB) & 0.68 & 0.74 & 0.040 \\
\hline & $\begin{array}{l}\text { Textiles, textile and leather } \\
\text { (TT) }\end{array}$ & 0.75 & 0.71 & -0.031 \\
\hline & Printing and publishing $(\mathrm{PP})$ & 0.43 & 0.38 & -0.053 \\
\hline & Fabricated metal (FM) & 0.57 & 0.62 & 0.047 \\
\hline & Other manufacturing $(\mathrm{OM})$ & 0.78 & 0.76 & -0.014 \\
\hline & Construction (CT) & 0.80 & 0.82 & 0.015 \\
\hline & $\begin{array}{l}\text { Wholesale and retail trade } \\
\text { (WR) }\end{array}$ & 0.60 & 0.57 & -0.023 \\
\hline & Hotels and restaurants (HR) & 0.52 & 0.56 & 0.036 \\
\hline & Transport and storage (TS) & 0.68 & 0.74 & 0.042 \\
\hline & $\begin{array}{l}\text { Real estate and Business } \\
\text { service (RB) }\end{array}$ & 0.80 & 0.78 & -0.008 \\
\hline & $\begin{array}{l}\text { Other social and personal } \\
\text { services (OS) }\end{array}$ & 0.78 & 0.79 & 0.010 \\
\hline & Average & 0.67 & 0.69 & 0.018 \\
\hline \multirow{9}{*}{ 4th quadrant } & Mining and quarrying (MQ) & 0.83 & 1.00 & 0.095 \\
\hline & $\begin{array}{l}\text { Wood, cork, pulp and paper } \\
\text { (WP) }\end{array}$ & 0.80 & 0.57 & -0.155 \\
\hline & $\begin{array}{l}\text { Coal and refined petroleum } \\
(\mathrm{CP})\end{array}$ & 0.88 & 0.94 & 0.035 \\
\hline & $\begin{array}{l}\text { Other non-metallic mineral } \\
\text { (NM) }\end{array}$ & 0.78 & 0.78 & -0.002 \\
\hline & Basic metals (BM) & 0.74 & 0.80 & 0.039 \\
\hline & Finance and insurance $(\mathrm{FI})$ & 0.63 & 0.60 & -0.032 \\
\hline & $\begin{array}{l}\text { Public admin and defense } \\
\text { (PA) }\end{array}$ & 0.69 & 0.64 & -0.030 \\
\hline & Education and health $(\mathrm{EH})$ & 0.86 & 0.85 & -0.006 \\
\hline & Average & 0.78 & 0.77 & -0.003 \\
\hline \multicolumn{2}{|c|}{ Average of total (a) } & 0.73 & 0.74 & 0.002 \\
\hline
\end{tabular}

Source: Drawn from GOMS 2005-3, 2007-3 data

Meanwhile, 'Work-major usefulness' by industry had declined in overall $\langle$ Table 10$\rangle$, contrasting with the overall increase of 'Work-major compatibility'. 1st quadrant displays the major usefulness of average 0.48 in 2008 and average 0.34 in 2010, declining in major usefulness in all the industries. Optical equipment industry in 2 nd quadrant also had decreased from 0.47 in 2008 to 0.32 in 2010 . While overall major usefulness in 3rd quadrant is not high, its major usefulness had decreased from average 0.39 in 2008 to average 0.32 in 2010. All the industries in the area, except Agriculture, forestry and fisheries industry had declined in major usefulness. 4th quadrant also displays low overall major usefulness, and it's getting even lower. Coal and refined petroleum industry was the only industry increased from 2008 at 0.5 to 2010 at 0.63 .

Table 10. 'Work-major usefulness' of newly employed university graduate (Within 3 years from graduation)

\begin{tabular}{|c|c|c|c|c|}
\hline classification & $\begin{array}{l}\text { IO } 28 \text { industry } \\
\text { classification }\end{array}$ & 2008 & 2010 & $\begin{array}{c}\text { annual } \\
\text { growth } \\
\text { rate }\end{array}$ \\
\hline \multirow{7}{*}{ 1st quadrant } & $\begin{array}{l}\text { Chemicals and chemical } \\
\text { (CC) }\end{array}$ & 0.53 & 0.32 & -0.221 \\
\hline & Machinery (MC) & 0.45 & 0.27 & -0.224 \\
\hline & Electrical equipment (EE) & 0.56 & 0.35 & -0.213 \\
\hline & $\begin{array}{l}\text { Transportation equipment } \\
\text { (TE) }\end{array}$ & 0.45 & 0.30 & -0.188 \\
\hline & $\begin{array}{l}\text { Electricity, gas and water } \\
\text { supply (GW) }\end{array}$ & 0.49 & 0.47 & -0.021 \\
\hline & $\begin{array}{l}\text { Post and telecommunications } \\
\text { (PT) }\end{array}$ & 0.37 & 0.31 & -0.073 \\
\hline & Average & 0.48 & 0.34 & -0.158 \\
\hline 2nd quadrant & Optical equipment (OE) & 0.47 & 0.32 & -0.170 \\
\hline \multirow{13}{*}{ 3rd quadrant } & $\begin{array}{l}\text { Agriculture, forestry and } \\
\text { fisheries (AF) }\end{array}$ & 0.31 & 0.45 & 0.206 \\
\hline & Food and beverages (FB) & 0.41 & 0.35 & -0.067 \\
\hline & $\begin{array}{l}\text { Textiles, textile and leather } \\
\text { (TT) }\end{array}$ & 0.45 & 0.37 & -0.088 \\
\hline & Printing and publishing (PP) & 0.29 & 0.08 & -0.481 \\
\hline & Fabricated metal (FM) & 0.31 & 0.26 & -0.091 \\
\hline & Other manufacturing $(\mathrm{OM})$ & 0.34 & 0.24 & -0.157 \\
\hline & Construction $(\mathrm{CT})$ & 0.48 & 0.47 & -0.017 \\
\hline & $\begin{array}{l}\text { Wholesale and retail trade } \\
\text { (WR) }\end{array}$ & 0.34 & 0.19 & -0.237 \\
\hline & Hotels and restaurants (HR) & 0.27 & 0.21 & -0.134 \\
\hline & Transport and storage (TS) & 0.38 & 0.34 & -0.053 \\
\hline & $\begin{array}{l}\text { Real estate and Business } \\
\text { service (RB) }\end{array}$ & 0.56 & 0.42 & -0.132 \\
\hline & $\begin{array}{l}\text { Other social and personal } \\
\text { services (OS) }\end{array}$ & 0.54 & 0.42 & -0.115 \\
\hline & Average & 0.39 & 0.32 & -0.097 \\
\hline \multirow{9}{*}{ 4th quadrant } & Mining and quarrying (MQ) & 0.83 & 0.33 & -0.368 \\
\hline & $\begin{array}{l}\text { Wood, cork, pulp and paper } \\
\text { (WP) }\end{array}$ & 0.43 & 0.29 & -0.184 \\
\hline & $\begin{array}{l}\text { Coal and refined petroleum } \\
(\mathrm{CP})\end{array}$ & 0.50 & 0.63 & 0.118 \\
\hline & $\begin{array}{l}\text { Other non-metallic mineral } \\
\text { (NM) }\end{array}$ & 0.51 & 0.22 & -0.347 \\
\hline & Basic metals (BM) & 0.49 & 0.39 & -0.104 \\
\hline & Finance and insurance (FI) & 0.35 & 0.24 & -0.181 \\
\hline & $\begin{array}{l}\text { Public admin and defense } \\
\text { (PA) }\end{array}$ & 0.42 & 0.30 & -0.156 \\
\hline & Education and health (EH) & 0.69 & 0.54 & -0.113 \\
\hline & Average & 0.53 & 0.37 & -0.167 \\
\hline \multicolumn{2}{|c|}{ Average of total (a) } & 0.45 & 0.34 & -0.138 \\
\hline
\end{tabular}

Source: Drawn from GOMS 2005-3, 2007-3 data

In overall aspect, quality Human Resource is suppressed to flow into manufacturing sector, while usefulness of major has been lowered, even though Work-major compatibility has been improved. Especially, it was so in the industries with high R\&D input. The effort for technological innovation with R\&D input appears not to be co-ordinate with Human Resource. This kind of difficulty in co-ordinance is limited not only to Human Resource Management of new Human Resource but displaying similar pattern in Adaptive ability development to new 
technology and Appropriate locating of existing Human Resource (Relocating by industry etc.). ${ }^{15}$ )

\section{ACHIEVEMENT OF STUDY \& FOLLOWING ISSUES}

This study analyzed in the explorative way that the expected innovation achievement can be realized when the learning process focusing on Human Resource aspects successfully coordinate with Innovation efforts such as R\&D. The analysis result displays restricted inflow of outstanding human resources to manufacturing sectors and lowering effectiveness of major even with the improved compatibility between major and job. Especially, it is severe in the industries with high R\&D investment. And that can be interpreted as an incoordination of the technological innovation efforts from the aspect of R\&D investment with human resource utilization from the aspect of new human resource. These analysis results and interpretation suggest active improvement on co-ordination by innovative manufacturers' efforts for technological innovation and human resource utilization, in order to sustain national innovation in the future.

The primary achievement of this study could be the efforts to integrate the problem of co-ordination between $R \& D$ and Human Resource being raised in theoretical dimension into national level innovation policy through analysis by industry unit. This can provide the proving ground for Co-ordination among R\&D human resources in Post catching-up stage, which also expands the concept of Viotti's [12] National Learning System(NLS) in theoretical dimension. Meanwhile, this kind of analysis was acquired by cross analyzing R\&D input and effect by industry through recomposing Input-Output table, and data on Work-major compatibility and usefulness using Graduates Occupational Mobility Survey (GOMS) through recomposing by industry. This creation of analysis data and searching on analysis method by using that can be called additional study achievements in the process of this study but it can also be the key contribution founding in this study.

But this study has not thoroughly verified the problem of coordination between R\&D and Human Resource suppressing the expansion of R\&D ripple effect. And the detailed analysis on the cause of this co-ordination difficulty has not been deployed. Study on co-ordination of Human Resource for technological change had been tried in Hwang[11], and the study that concurrenting that method with current study is on the way. There are the limitation of this study should be carried out by further study. For that matter, combining additional data (i.e. patent data by industry), utilizing panel data based on time series by industry, and applying industry sub-classification can be employed in the following related study.

\section{REFERENCES}

[1] W. Song, J. Sung, Y. Kim, H. Hwang and J. Chung, In Search of Post Catch-up Innovation System, Science \&

15) Many related studies on Re-education \& training of existing HR, and Mobility and relocation of existing HR among industry [13] [14], support this.
Technology Policy Institute, 2006. (in Korean)

[2] H. Hwang, J. Chung, and W. Song, "Theoretical direction \& task for Post catching-up study," Technology Innovation Research, vol. 20, no. 1, 2012. (to be published in Korean)

[3] C. Freeman, "Japan: a new national system of innovation?" in G. Dosi, C. Freeman, R. Nelson, G. Silverberg, and L. Soete (eds), Technical Change and Economic Theory, Pinter, 1998, pp. 330-348.

[4] R. R. Nelson, , "Institutions supporting technical change in the United States," in G. Dosi, C. Freeman, R. Nelson, G. Silverberg, and L. Soete (eds), Technical Change and Economic Theory, Pinter, 1988, pp. 312-329.

[5] B. A. Lundvall, "Innovation as an interactive process: from user-producer interaction to the national system of innovation", in G. Dosi, C. Freeman, R. Nelson, G. Silverberg, and L. Soete (eds), Technical Change and Economic Theory, Pinter, 1998, pp. 349-369.

[6] C. Edquist (ed.), Systems of Innovation, Pinter, 1997.

[7] L. Kim, "National Systems of Industrial Innovation: Dynamics of Capability Building," in R.R. Nelson (ed), National Innovation Systems, OUP, 1993, pp. 357-383.

[8] L. Kim, Imitation to Innovation: The Dynamics of Korea's Technological Learning, Harvard Business School Press, 1997.

[9] M. Gibbons, C. Limoges, H. Nowotny, S. Schwartzman, P. Scott, P. and M. Trow, The New Production of Knowledge: The Dynamics of Science and Research in Contemporary Societies, London: SAGE, 1994.

[10] M. Gibbons. "Mode 2 society and the emergence of context-sensitive science", Science and Public Policy, vol. 27, no. 3, 2000, pp. 159-163.

[11] G. Hwang, W. Shim, and B. Coh, "Analysis of Knowledge Base and Future Skills Needs through Patentometrics- Case of Battery Industry," Journal of Korea Technology Innovation Society, vol. 13, no. 3, 2011, pp. 399-422. (in Korean)

[12] E. B. Viotti, "National Learning Systems: A new approach on technological change in late industrializing economies and evidences from the cases of Brazil and South Korea", Technological Forecasting and Social Change, vol. 69, no. 7, 2002, pp. 653-680.

[13] Business statistics system of the Bank of Korea, http://ecos.bok.or.kr

[14] R. E. Miller and P. D. Blair, Input-Output Analysis: Foundations and Extensions ( $2^{\text {nd }}$ edition), CUP, 2009.

[15] University graduate job migration channel survey(GOMS), http://survey.keis.or.kr/survey keis

[16] A. Kim, E. Lim, J. Choi, H. Ryu, K. Kim, The Socioeconomic Effects Related Higher Education Expansion in Korea, KRIVET, 2011.(in Korean)

[17] Z. Griliches, "Capital-skill complementarity," Review of Economics and Statistics, vol. 51, no. 4, 1969, pp. 465468.

[18] E. Berman, J. Bound and S. Machin, "Implications of skill-biased technological change: international evidence," Quarterly Journal of Economics, vol. 113, no. 
4, 1998, pp.1245-1279.

[19] R.R. Nelson and E.D.S. Phelps, "Investment in human, technological diffusion, and economic growth," American Economic Review, Paper \& Proceedings, 54, 1965, p. 69-75.

[20] S. Lee S. Lee, S. Yoon, The Forecasting of Vocational Training Demands according to the Changes of Industrial Structure, KRIVET, 2002. (in Korean)

[21] Y. Ra, Y. Park, K. Ryu, P. Baik, C. Lee and J. Chung, Mid-to-small business training vitalizing plan, Ministry of Labor/KRIVET, 2011. (in Korean)

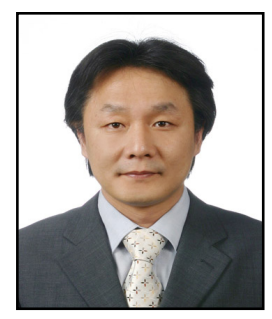

\section{Gyu-hee Hwang}

Acquired Doctoral degree from SPRU in the UK. Working for KRIVET as research fellow. Main research area is developing and utilizing HRST(Human Resource in Sci-Tech). Recently focusing on future skills needs and knowledge forming. 